\title{
Risk Assessment of Heavy Metals in Food Crops at Abandoned Lead-Zinc Mining Site at Tse-Faga, Logo, Lga, Benue State, Nigeria
}

\author{
Paul N. Samuel1,2, Bolaji B. Babatunde ${ }^{2 *}$ \\ ${ }^{1}$ World Bank Africa Center of Excellence for Public Health and Toxicological Research (ACE-PUTOR), University of Port \\ Harcourt, Choba, Port Harcourt, Rivers State, Nigeria \\ ${ }^{2}$ Animal and Environmental Biology Department, University of Port Harcourt, Choba, Port Harcourt, Rivers State, Nigeria \\ Email: ^bolaji.babatunde@uniport.edu.ng
}

How to cite this paper: Samuel, P.N. and Babatunde, B.B. (2021) Risk Assessment of Heavy Metals in Food Crops at Abandoned Lead-Zinc Mining Site at Tse-Faga, Logo, Lga, Benue State, Nigeria. Journal of Environmental Protection, 12, 624-638. https://doi.org/10.4236/jep.2021.129038

Received: August 17, 2021

Accepted: September 24, 2021

Published: September 27, 2021

Copyright (C) 2021 by author(s) and Scientific Research Publishing Inc. This work is licensed under the Creative Commons Attribution International License (CC BY 4.0).

http://creativecommons.org/licenses/by/4.0/

\begin{abstract}
Hundreds of children died in 2010 due to suspected lead poisoning from mining sources in Zamfara State among epidemiological concerns. Evaluating ecological and human health risks of heavy metals levels in sampled food crops harvested near two abandoned Lead-Zinc mining sites at Logo Benue State is crucial. Abelmoschus esculentus, Carica papaya, Manihot esculenta, and Zea mays were sampled, prepared, and analyzed for four heavy metals using the Atomic Absorption Spectrophotometric method. The mean data from the analysis of variance was subjected to ecological and health risk models. $\mathrm{Pb}$ means value ranged from Carica papaya Peel $0.46 \pm 0.011 \mathrm{mg} / \mathrm{kg}$ to $1.30 \pm 0.01 \mathrm{mg} / \mathrm{kg}$ in Zea mays seed. Zn was highest in Carica papaya flesh $0.50 \pm 0.01 \mathrm{mg} / \mathrm{kg}$, and lowest in Manihot esculenta peels and its flesh $0.12 \pm$ $0.000 \mathrm{mg} / \mathrm{kg}$. Hg and Cd were below detectable levels. Zea mays seeds (1.001) had the highest Pd bioaccumulation factor. BAF of zinc and ecological indices were $<1$. Daily Intake of Metals were all $<1$, however, Hazard Quotient (HQ) of $\mathrm{Pb}$ was $\geq 1$ in Manihot esculenta flesh 1.143 and Zea mays at 1714. Cancer Risks were within permissible range $\left(10^{-4}-10^{-6}\right)$. Health Risk result indicates communities around the mining area may be at risk of lead poisoning therefore due to high contamination of samples, routine checks on heavy metals especially lead is recommended to prevent excessive bioaccumulation in the body.
\end{abstract}

\section{Keywords}

Mining, Food Crops, Heavy Metals, Ecological Risk, Health Risks, Lead Poisoning 


\section{Introduction}

The environmental consequences of the human interactions with nature through mining are highly detrimental to both human and environmental health, lead poisoning, air, and water pollution are some of the risks associated with this venture across Nigeria [1] [2].

The revenue generated from this sector, however, has saved the country massive finances, some of these monies have been used in funding many government programs ranging from infrastructural design and development, education, health care, etc. [3]. However, informal miners and companies have become very active recently in the production of solid minerals without having a clearly defined policy, standard regulatory document as well as reforms [4]. About 223 small-scale mining operations, 195 mining leases, 845 artisanal mining cooperatives were documented and 2048 exploration licenses were issued in the country [5]. The operations of the above have resulted in widespread ecological impacts at the expense of adjacent communities. So many abandoned mines across the country have become major sources of environmental hazards [6]. The levels of toxic residues from zinc and geological hazards among other issues such as the destruction of flora and fauna are threats posed by mining [7]. These challenges are massively emanating from the activities of artisanal and small-scale mining.

Mining fields in Jos, Barkin-Ladi, Bukuru, Bossa and Riyom districts have generated hazards to the people of Plateau for many years now Figure 1. [8] [9] all agreed that mining ponds with high levels of radiation could be the cause of mysterious deaths in areas that used high levels of monazite-rich sand for building.

History has it that, there are about 1100 to 4000 tin and columbite mines,

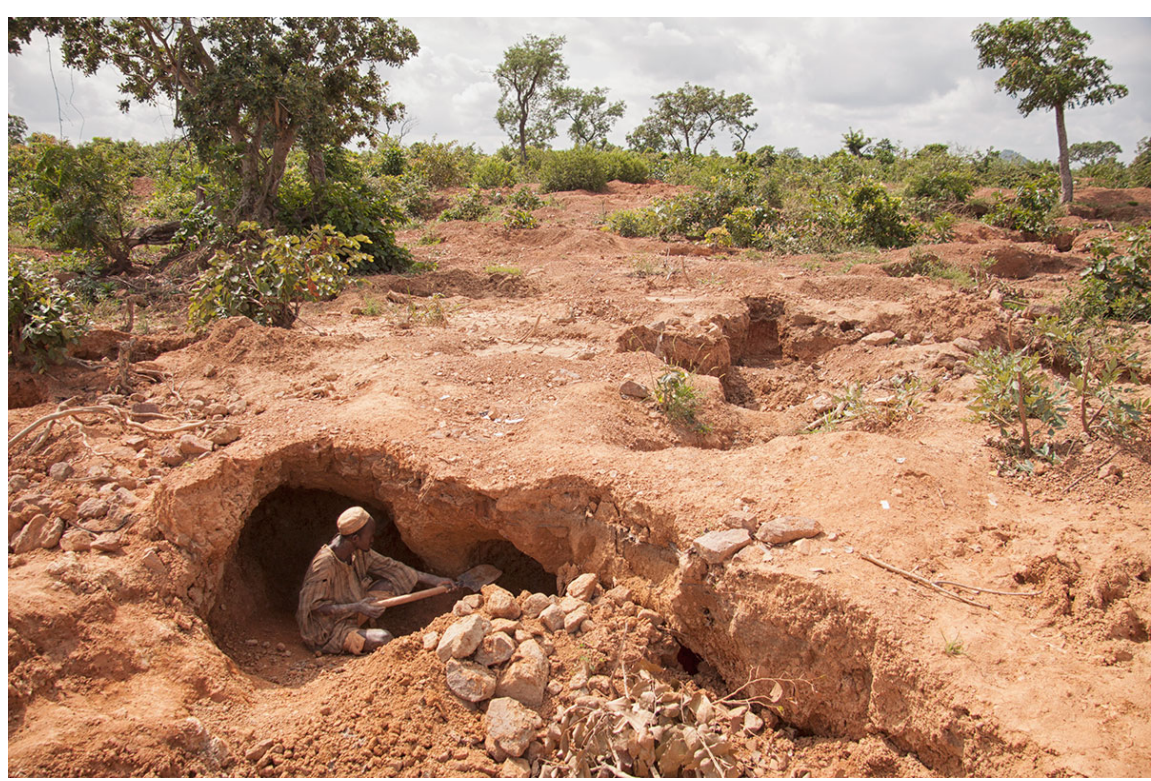

Figure 1. Picture of artisan mining pits in northern Nigeria. Content source: [14]. 
which were abandoned after the mining boom of the 1960s, these mines now pose serious health hazards to almost 2 million residents in Jos [10] [11].

The residents of these communities are exposed to a whopping $325 \mathrm{~km}^{2}$ of contaminated lands by carcinogenic radioactive materials through indiscriminate disposal of mining wastes with brain-damaging potentials in the Jos plateau [11] and [12]. In the year 2015, there were death occurrences caused by mining in the Madaka Rafi Local government of Niger State, and also along with the Kawo village near the lower stream of the River Kaduna known for the mining of gems and gold with more devastating effects [13].

In the year 2010, over 400 children died from confirmed cases of lead poisoning from lead mining in Zamfara state northern Nigeria. Between April and May 2015, 3000 residents of in Kawo and Magiro villages have been exposed to the lead, while 28 children mysteriously died days after suffering symptoms of convulsions, insomnia and hallucinations [15]. Paul and Babatunde [16] (Table 1) reported high levels of leads in the water as a result of Lead-Zinc Mining from Yonov district in Logo Local Government area in Benue state. The need to carry out this research cannot be over-emphasized due to the devastating impact of lead poisoning on human health, which is translated to poor economies, over-stressed health delivery systems and subsequent death rates.

\section{Materials and Methods}

\subsection{Scope of the Study}

The scope of the present study was limited to the risk assessment of heavy metals $(\mathrm{Pb}, \mathrm{Cd}, \mathrm{Zn}$, and $\mathrm{Hg})$ in food crops at an abandoned lead-zinc mining site at Tse-Faga, in Logo Local Government Area of Benue State.

\subsection{Study Area}

Logo local government is located between latitude $7^{\circ} 29^{\prime \prime}$ and $7^{\circ} 52^{\prime \prime}$ north of the Equator and longitude $9^{\circ} 05^{\prime \prime}$ and $9^{\circ} 20^{\prime \prime}$ east of the Greenwich Meridian Figure 2. It is bonded to the East by Ukum, to the North-West by Guma, to the West by Buruku, to the south by Katsina-Ala Local Government Area of Benue State and to the North by Wukari Local Government Area of Taraba state, [17] according to the 2006 census exercise, the local government has an area of $1408 \mathrm{~km}^{2}$ and a population of 169,570 .

\subsection{Sample Collection and Preparation}

Food crops (Abelmoschus esculentus, Carica papaya, Manihot esculenta, and Zea mays) were collected randomly on the farms directly from the farmers around the abandoned Lead-Zinc mining site at Tse-Faga in Logo Local Government Area of Benue State and neatly packaged in zip-lock bags, labeled accordingly and conveyed to the and transported to the Powel and B Toxicology and Biodiversity Laboratory, Department of Animal and Environmental Biology University of Port Harcourt, Choba, Rivers State for sample preparation and laboratory analysis. 


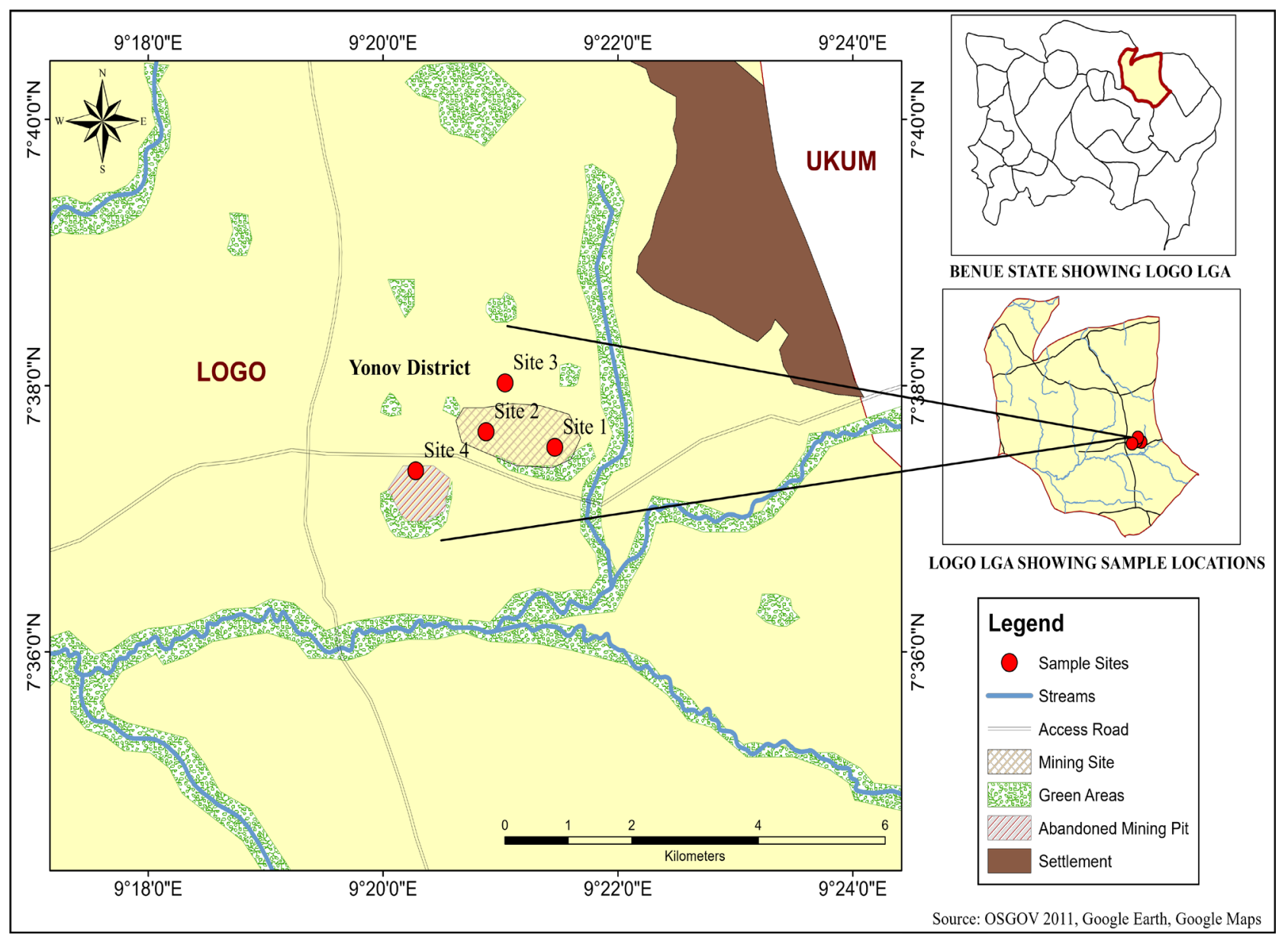

Figure 2. Map of study.

\subsection{Sample Preparation}

All collected samples were separated accordingly, the outer parts such as peels ad shells were separated from the inner parts such as seeds, tuber, flesh respectively. The separation of samples into the various components was aimed at assessing the different concentration of the metals in the different sample components.

Samples were the oven dried to reduce moisture, grinded, and sieved properly using a 300 microns sieve for proper surface area for Laboratory analysis.

Atomic absorption spectrophotometric methodology was used for this analysis at Giolee Global Services Limited, Port Harcourt.

\subsection{Sample Digestion}

One gram (1 g) of each food crop was measured into a $250 \mathrm{ml}$ conical flask, $10 \mathrm{ml}$ of well mixed (Perchloric, Nitric and Sulphuric acid) was introduced into the solution and allowed to soak. Digestions were done in a fume cupboard. The heated samples were cooled off, filtered and the filtrates introduced into a 100-ml laboratory volumetric flask and prepared for heavy metal analysis using an atomic absorption spectrophotometer (AAS) and the results were printed out in three decimal points. 


\subsection{Data Analysis Methods}

\section{Statistical analysis}

The statistical analysis of data was done using SPSS 21 software (IBM) Corporation, Armonk, NY, USA). The means of the different results were analyzed using a one-way analysis of variance (ANOVA). Post-Hoc Tukey HSD test was done to verify statistically significant differences among individual means at $\mathrm{P} \leq$ 0.05 .

\subsection{Ecological Risk Assessment}

\section{Bioaccumulation Factor (BAF) of Metals in Biota Samples}

The bioaccumulation factor (BAF) is the relative tendency of a substance to be accumulated by a certain species of plant or animal. It is the ratio of the concentration of heavy metal in a plant to the levels of such heavy metal in soil, which is described as [18]

$$
\mathrm{BAF}=\frac{\text { Concentration in crop }}{\text { Concentration in soil }}[19]
$$

where:

Concentration of $\mathrm{Pb}$ in soil was $1.30 \mathrm{mk} / \mathrm{kg}$;

Zinc levels in soil were 0.67 [15].

\section{Contamination Factor (CF)}

C. Factor (CF) is basically used to assess the extent of sample contamination by heavy metals. It is expressed as the ratio of the concentration of the heavy to the background value. The background value used in this work is the standard value stipulated by USEPA 2011. The contamination factor does not have a unit of expression.

$$
\mathrm{CF}=\frac{C \cdot \text { metal }}{B n}
$$

where:

$C$ metal is the metal concentration in polluted media;

$B n$ is the background value of that metal.

\section{Pollution Load Index (PLI)}

The Pollution Load Index (PLI) evaluates the degree to which the soil sediment associated which heavy metal which might impact the microflora and fauna of soil. It can be used to check the levels of heavy metal contamination [20].

$$
\mathrm{PLI}=\sqrt[n]{\left(\mathrm{CF}_{1} \times \mathrm{CF}_{2} \times \mathrm{CF}_{3} \times \mathrm{CF}_{4} \cdots \mathrm{CF}_{n}\right)}
$$

where $\mathrm{CF}$ represent the contamination factor, $\mathrm{n}$ is the number of metals investigated, The PLI is scored using a scale from 0 - 6 .

The Geo-Accumulation Index (Igeo) of Metals in Biota, Soil and Water Samples

The geo-accumulation factor is an indicator to assess the presence and inten- 
sity of anthropogenic contamination. It is expressed as:

$$
\text { Igeo }=\log 2\left(\frac{C n}{1.5 B n}\right)
$$

$C n=$ concentration of metal in the soil, $B n$ is the geochemical background for the element and 1.5 is a constant.

\subsection{Human Health Risk Assessment of Heavy Metals}

The estimated daily intake of metals is used to ascertain the health risk related to the intake of heavy metals from food crops, water, and exposure to soil. The Estimated Daily Intake (EDI) Hazard Quotient (HQ), Hazard Index (HI) and Cancer Risk ( $\mathrm{Cr}$ ) were also considered. The estimated daily intake of metals is expressed in $\mathrm{Mg} / \mathrm{kg} / \mathrm{day}^{-1} \mathrm{Bw}$.

Estimated Daily Intake of Metal (EDIM)

$$
\mathrm{EDIM}=\frac{\mathrm{CM} \times \mathrm{DFI}}{\mathrm{BW}}
$$

where CM is the Concentration of metal in crop;

DFI is the Daily food intake $=0.3 \mathrm{mg} / \mathrm{kg}$ [21] [22];

BW is the Body Weight average (62 kg assumed).

The Hazard Quotient (HQ) of Heavy Metals in food-crops samples

$$
\mathrm{HQ}=\frac{\mathrm{EDIM}}{\mathrm{RfD}}
$$

where:

RfD is Oral slope factor in $\mathrm{mg} / \mathrm{kg} /$ day according to USEPA guideline [23].

When $\mathrm{HQ}<1$ metal contamination is still within safe limits. Whereas HQ $\geq 1$ means it has potential to cause disease [22].

Carcinogenic risk $(\mathrm{Cr})$

$$
\mathrm{Cr}=\mathrm{EDI} \times \mathrm{CSF}
$$

where Cr represents the cancer risk;

EDI is the estimated daily intake calculated in equation (V);

CSF is the cancer slope factor.

According to USEPA [24] $10^{-6}-10^{-4}$ is the range of permitted assumed lifetime risks for carcinogens.

Table 1. Reference values for different parameters.

\begin{tabular}{cccc}
\hline & \multicolumn{3}{c}{ ELEMENTS (mg/kg/day) } \\
\hline REFERENCE VALUES & $\mathrm{Pb}$ & $\mathrm{Zn}$ & REFERENCE \\
\hline Toxic reference factor & 5 & 1 & {$[25]$} \\
Geochemical background value $(B n)$ & 20 & 95 & {$[26]$} \\
Background value of element & 85 & 140 & {$[26]$} \\
Oral reference doses (RfD) mg/kg/day & 0.3 & 0.004 & {$[27][28]$} \\
Cancer slope factor & 0.0085 & - & {$[29]$} \\
\hline
\end{tabular}




\section{Results and Discussion}

\subsection{Heavy Metals Concentration the Food-Crops}

Results in Table 2 below shows concentration of heavy metals in food crops, lead $(\mathrm{Pb})$ was highest in maize seed $(1.30 \mathrm{mg} / \mathrm{kg})$ while the lowest mean concentration values were recorded in Manihot esculenta peel, Carica papaya peel, and with mean values of $0.46 \pm 0.02 \mathrm{mg} / \mathrm{kg}, 0.46 \pm 0.019 \mathrm{mg} / \mathrm{kg}, 0.46 \pm 0.0164 \mathrm{mg} / \mathrm{kg}$ respectively. These results are relatively higher than the results of [30] 0.202 $0.134 \mathrm{mg} / \mathrm{kg}$ for higher and lower limits respectively.

These results have revealed alarming levels of Lead in food crops such as Zea mays seeds as high as $130 \%$ to $45 \%$ and Carica papaya peel above the standard level of $0.1 \mathrm{mg} / \mathrm{kg}$ stipulated by World Health Organization [31].

Generally, zinc $(\mathrm{Zn})$ concentration in all the food crops from the mining site revealed the highest concentration in Carica papaya with mean concentration and standard deviation of $0.50 \pm 0.01 \mathrm{Mg} / \mathrm{kg}$ while the lowest mean concentration values were recorded in Manihot esculenta peel $0.122 \pm 0.01 \mathrm{mg} / \mathrm{kg}$ (Table 2). [32] reported values of $1.205-1.017 \mathrm{mg} / \mathrm{kg}$, [33] reported lead increase over a post spill event from NDL to $0.16 \mathrm{mg} / \mathrm{kg}$ over seasons. These results are relatively higher than the results of this work. All the concentrations of zinc in the food crops were below the stipulated standard by WHO. These results are significantly lower than the reports of [34] who report mean value of Iron, Copper, Manganese, Lead, Zinc, Chromium, Arsenic, and Cadmium in station 1 of his study area from $3.55-9454.0 \mathrm{mg} / \mathrm{kg}$.

Table 2, revealed a trend of higher mean concentrations of lead $(\mathrm{Pb})$ in the inner parts of the food crops than in the outer parts. [35] reported that lead/zinc mining areas accumulate significant levels of Cadmium, he noted that, vegetables have higher tendencies to accumulate Cadmium and lead $(\mathrm{Pb})$ than the other heavy metals, however, the results in Table 2 and Figure 1 of this study contrasted this claim hence concentration of cadmium was below detectable limits. Figure 1 revealed higher centration of lead $\mathrm{Pb}$ in all analyzed food-based samples, with maize seeds accumulating the highest level of lead $(\mathrm{Pb})(1.30$ $\mathrm{mg} / \mathrm{kg}$ ).

The presence of heavy metals in food crops and plants, in general, has been

Table 2. Mean concentration of metals in food crops.

\begin{tabular}{ccccc}
\hline SAMPLE CODE & $\mathrm{Pb} \mathrm{Mg} / \mathrm{Kg}$ & $\mathrm{Hg} \mathrm{Mg} / \mathrm{Kg}$ & $\mathrm{Cd} \mathrm{Mg} / \mathrm{Kg}$ & $\mathrm{Zn} \mathrm{Mg} / \mathrm{Kg}$ \\
\hline Manihot esculenta Peels & 0.46 & $<0.001$ & $<0.002$ & 0.12 \\
Manihot esculenta Flesh & 0.89 & $<0.001$ & $<0.002$ & 0.12 \\
Carica papaya Peels & 0.46 & $<0.001$ & $<0.002$ & 0.46 \\
Carica papaya Flesh & 0.89 & $<0.001$ & $<0.002$ & 0.50 \\
Zea mays Husk & 0.67 & $<0.001$ & $<0.002$ & 0.26 \\
Zea mays Seed & 1.30 & $<0.001$ & $<0.002$ & 0.46 \\
Abelmoschus esculentus & 0.67 & $<0.001$ & $<0.002$ & 0.48 \\
\hline
\end{tabular}


confirmed to be of deleterious effects due to the very critical roles they play in the food chain. Herbivorous animals take in these metals thereby, transferring the metals through higher organisms in the food chain as these higher animals such as humans, while some omnivores feed directedly on the plants.

There was no significance difference in the mean concentration of lead $(\mathrm{Pb})$ at $\mathrm{P} \leq 0.05$ in Manihot esculenta tuber flesh, Carica papaya flesh, and zeal mays seeds, also, no significance difference was observed in the mean concentration of lead $(\mathrm{Pb})$ at $\mathrm{P} \leq 0.05$ in Zea mays husk and Abelmoschus esculentus and finally no significance difference in the mean concentration of lead $(\mathrm{Pb})$ at $\mathrm{P} \leq 0.05$ in Manihot esculenta peel, and Carica papaya peel.

In the mean concentration of Zinc ( $\mathrm{Zn}$ ), there was no significance difference at $\mathrm{P} \leq 0.05$ in Manihot esculenta peel, and Manihot esculenta tuber flesh, Carica papaya peel, Carica papaya flesh, and Abelmoschus esculentus while there was a significance difference between Zea mays husk, Zea mays seeds and the other samples.

\subsection{Bioaccumulation of Heavy Metals}

Transfer factor is the ability of a metal to be accumulated by a particular species of plant. It is the ratio of the concentration of heavy metal in a plant to the concentration of heavy metal in soil. The bioaccumulation factor (BAF) of heavy metals from soil to plants of the study area is represented in Figure 3. The highest bioaccumulation factor of lead (Pd) was revealed Zea mays seeds (1.001) while Manihot esculenta tuber peel and Carica papaya peels with BAF value of 0.358 was the lowest.

The highest bioaccumulation factor (BAF) of zinc was recorded in Carica papaya flesh 0.754 , Manihot esculenta tuber peels and flesh 0.181 was the lowest.

1.200

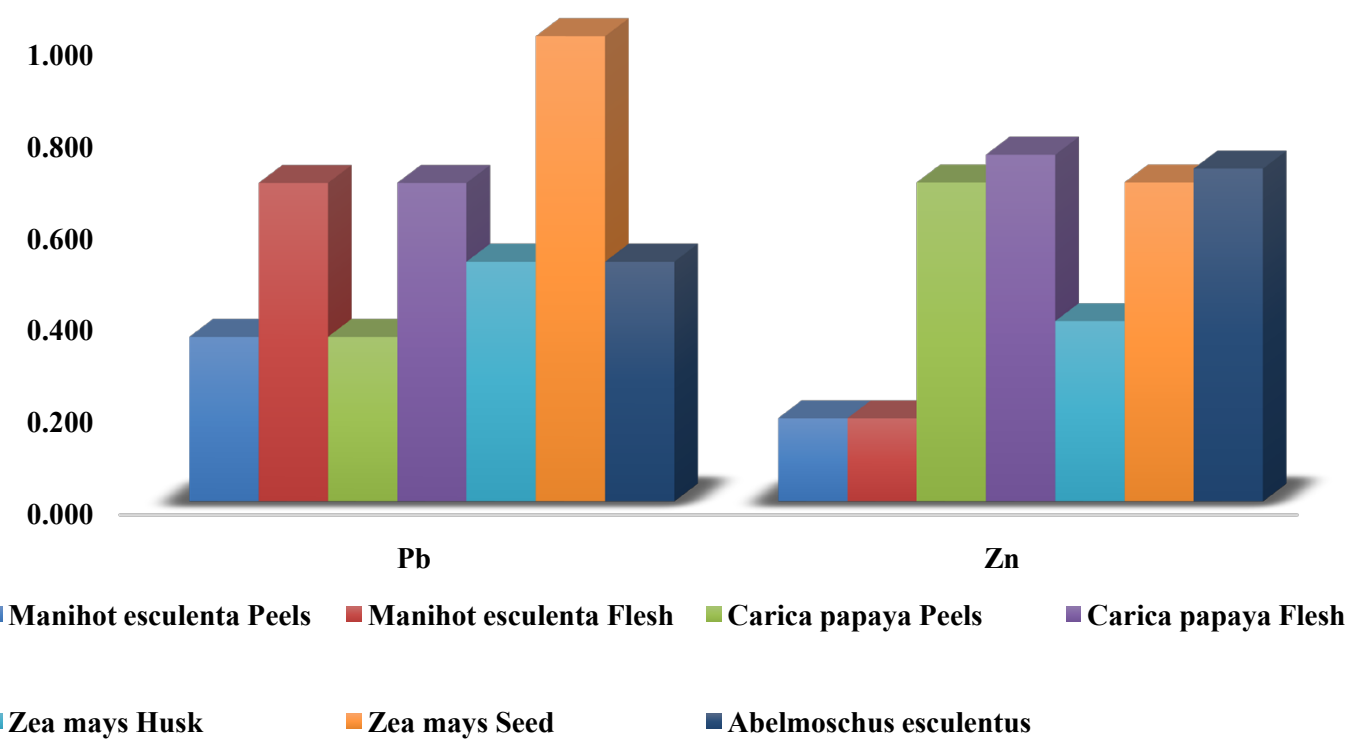

Figure 3. Bioaccumulation of Heavy metals in food crops from study area. 
All the results of transfer factor of Zinc from soils to food crops were below the stipulated standard of BAF > 1, according to [33]. However, Zea Mays with BAF 1.011 was recorded the highest BAF, we can therefore conclude that, among all food crops under study, Zea Mays had the highest bioaccumulation factor.

\subsection{Ecologicl Risk Assessment Risk}

\subsubsection{Contamination Factor (CF) and Pollution Load Index (PLI)}

Results are presented in Table 3. Reveal the Pollution load index (PLI) of the analyzed samples. PLI recorded in this study were below one (1), which signifies that, even though the contamination of the individual sample by lead $(\mathrm{Pb})$ was high in all food crops samples, the pollution load index for all the samples showed non-contamination according to the pollution load index ranking. The results of the present study are in agreement with the findings of [35] who report PLI value of $<1$ in station 1 of his study, however, he reported PLI value $>1$ in the remaining two stations of his study area.

\subsubsection{Geo-Accumulation Index (Igeo)}

Figure 4 below shows the geo-accumulation index of food-crops as follows: Manihot esculenta peel 0.00026, Manihot esculenta tuber flesh 0.00026, Carica papaya peel 0.00096, Carica papaya flesh 0.00011, Zea mays husk 0.00055, Zea mays seed 0.00097, Abelmoschus esculentus 0.0001 for Zinc (Zn), while geoaccumulation of lead $(\mathrm{Pb})$ was as follows: Manihot esculenta peel, 0.00458, Manihot esculenta tuber flesh, 0.00893, Carica papaya peel, 0.00458, Carica papaya flesh, 0.00893. Zea mays husk, 0.00675, Zea mays seed, 0.013, Abelmoschus esculentus, 0.00675 .

Geo-accumulation index of Mercury (Hg) and Cadmium (Cd) was not calculated for, hence their concentrations in the biota (food crops) were all below lowest detectible limits of the atomic absorption spectrometer.

All the results from this study were lower than the results reported by [36] who report Igeo range of $0.00213-0.0194$ for lead $(\mathrm{Pb})$ and $0.0247-0.0172$ for zinc. Hence all figures fall below the stipulated values of $<1$ signifies that these samples are safe from contamination according to this ranking.

Table 3. Contamination factor (CF) and pollution load index (PLI) of heavy metals in biota, water and soil samples.

\begin{tabular}{|c|c|c|c|}
\hline \multirow[b]{2}{*}{ Samples } & \multicolumn{2}{|c|}{ Contamination Factor } & \multirow[t]{2}{*}{ Pollution Load Index } \\
\hline & $\mathrm{Pb}$ & $\mathrm{Zn}$ & \\
\hline Manihot esculenta peel & 0.005 & $8.7 \mathrm{E}-04$ & 0.00209 \\
\hline Manihot esculenta tuber flesh & 0.01 & $8.7 \mathrm{E}-04$ & 0.00295 \\
\hline Carica papaya peel & 0.005 & 0.003 & 0.00387 \\
\hline Carica papaya flesh & 0.01 & 0.004 & 0.00632 \\
\hline Zea mays husk & 0.008 & 0.002 & 0.004 \\
\hline Zea mays seed & 0.015 & 0.003 & 0.00671 \\
\hline Abelmoschus esculentus & 0.008 & 0.003 & 0.0047 \\
\hline
\end{tabular}




\section{IGEO}

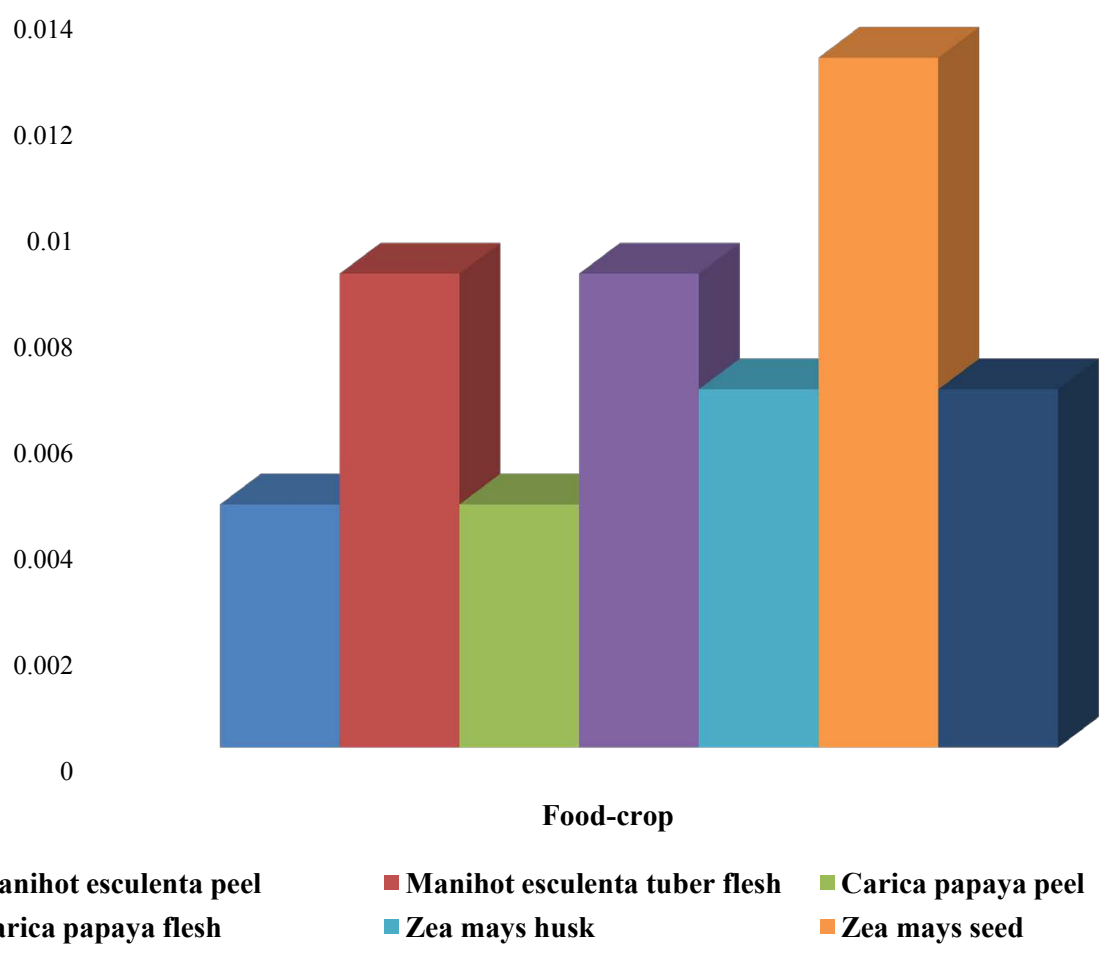

- Manihot esculenta pee

Manihot esculenta tuber flesh

Zea mays seed

- Abelmoschus esculentus

Figure 4. Geo-accumulation index (Igeo).

\subsection{Human Health Risk Assessment of Heavy Metals}

\subsubsection{The Estimated Daily Intake of Heavy Metals in Food-Crops Samples}

The EDI of $\mathrm{Pb}$ through the consumption of Biota foodstuffs as represented in Table 4 to range from, 0.002 to $0.006 \mathrm{mg} / \mathrm{kg}$ (Manihot esculenta peel, Carica papaya peel \& flesh Zea mays seeds), while $\mathrm{Zn}$ was 5.9E-04 (Manihot esculenta peel and Manihot esculenta tuber flesh) to $0.002 \mathrm{mg} / \mathrm{kg}$ (Carica papaya Peel, Carica papaya Flesh, Zea mays Seed and Abelmoschus esculentus).

It is deduced from the values in Table 4 below that, the daily intake of heavy metals via food crops of the study area is nearly free of potential risk hence the values of the estimated daily intake of the metals in food fall far below set standards. The results here are lower than reports of other studies including that of [37].

\subsubsection{The Hazard Quotient (HQ) of Heavy Metals in Food-Crops Samples} The HQ of $\mathrm{Pb}$ in revealed in Table 5 showed a range from Zea mays seed 1.714, cassava flesh 1.143, Abelmoschus esculentus 0.857 Zea mays husk 0.857, Manihot esculenta peel, Carica papaya peel and Carica papaya Flesh all at 0.571. Zea mays seeds and Manihot esculenta peel with HQ above recommended standard value of 1 . These results were higher than the report of [38]. Who reported the maximum value of HQ in biota to be 1.111 . 
Table 4. Estimated daily intake (EDI) of heavy metals in food crops.

\begin{tabular}{ccccc}
\hline Samples & $\mathrm{Pb}$ & $\mathrm{Zn}$ & $\mathrm{Hg}$ & $\mathrm{Cd}$ \\
\hline Manihot esculenta Peel & 0.002 & $5.9 \mathrm{E}-04$ & - & - \\
Cassava tuber Flesh & 0.004 & $5.9 \mathrm{E}-04$ & - & - \\
Carica papaya Peel & 0.002 & 0.002 & - & - \\
Carica papaya Flesh & 0.002 & 0.002 & - & - \\
Zea mays Husk & 0.003 & 0.001 & - & - \\
Zea mays Seed & 0.006 & 0.002 & - & - \\
Abelmoschus esculentus & 0.003 & 0.002 & - & - \\
RfDo & $\mathbf{0 . 0 0 3 5}$ & $\mathbf{0 . 3}$ & - & - \\
\hline
\end{tabular}

Table 5. Hazard quotient (HQ) of heavy metals in food crops.

\begin{tabular}{ccc}
\hline SAMPLE & $\mathrm{Pd}$ & $\mathrm{Zn}$ \\
\hline Manihot esculenta peel & 0.571 & 0.002 \\
Manihot esculenta flesh & 1.143 & 0.002 \\
Carica papaya peel & 0.571 & 0.007 \\
Carica papaya Flesh & 0.571 & 0.007 \\
Zea mays husk & 0.857 & 0.003 \\
Zea mays seed & 1.714 & 0.007 \\
Abelmoschus esculentus & 0.857 & 0.007
\end{tabular}

Table 6. Carcinogenic risk (Cr) of heavy metals in food crops.

\begin{tabular}{ccccc}
\hline Samples & $\mathrm{Pb}$ & $\mathrm{Cd}$ & $\mathrm{Hg}$ & $\mathrm{TCR}$ \\
\hline Manihot esculenta peel & $1.7 \mathrm{E}-05$ & - & - & $1.7 \mathrm{E}-05$ \\
Manihot esculenta tuber flesh & $3.4 \mathrm{E}-05$ & & - & $3.4 \mathrm{E}-05$ \\
Carica papaya peel & $1.7 \mathrm{E}-05$ & - & - & $1.7 \mathrm{E}-05$ \\
Carica papaya flesh & $1.7 \mathrm{E}-05$ & - & - & $1.7 \mathrm{E}-05$ \\
Zea mays husk & $2.6 \mathrm{E}-05$ & - & - & $2.6 \mathrm{E}-05$ \\
Zea mays seed & $5.1 \mathrm{E}-05$ & - & - & $5.1 \mathrm{E}-05$ \\
Abelmoschus esculentus & $2.6 \mathrm{E}-05$ & - & - & $2.6 \mathrm{E}-05$ \\
STANDARD & $10^{-6}$ to $10^{-4}$ & & & \\
\hline
\end{tabular}

Hazard quotient for $\mathrm{Zn}$ in the analyzed samples ranged from 0.002 to 0.007 (Manihot esculenta peel, cassava to Carica papaya peel and Carica papaya Flesh, Zea mays seeds and Abelmoschus esculentus) for $\mathrm{Zn}$ respectively (Table 5). It is worthy of note that, the hazard quotient of $\mathrm{Zn}$ in all the analyzed samples was less than 1 , which simply means, the probability of health risk or toxicity to the residents originating from the ingestion of $\mathrm{Zn}$ via the consumption, ingestion, or exposure to the food crops by the populace very low compared to $\mathrm{Pb}$. 


\subsubsection{Cancer Risk (Cr) of Heavy Metals in Food Crops Samples}

Table 6 shows the cancer risk of $\mathrm{Pb}$ was within the range $\left(10^{-6}\right.$ to $\left.10^{-4}\right)$ USEPA (2011) of predicted lifetime risk for cancer-causing substances, which indicates that, the risk of developing cancer from consuming $\mathrm{Pb}$ via the consumption of the food crops by populace.

\section{Conclusions}

Results obtained from this research revealed significantly high levels of lead in all sampled food crops, all concentrations were above the standard recommendation of $0.01 \mathrm{mg} / \mathrm{kg}$ as stipulated by the WHO. Zea Mays seeds which recorded the highest concentration levels of Lead also recorded the highest values of bioaccumulation factor. Zinc levels in all samples were at safe levels as determined by the WHO. Ecological risk assessment revealed no contamination, however, human risk assessment revealed high non-carcinogenic risk in hazard quotient (HQ). This is an indication that the consumption of food crops cultivated around the abandoned mining areas may significantly increase the risk of noncarcinogenic diseases associated with lead poisoning. The probability of people exposed to heavy metals via the consumption of these food crops to develop cancer is low hence, carcinogenic risk values were within the stipulated range of $\left(10^{-6}\right.$ to $\left.10^{-4}\right)$ by the United State Environmental Protection Agency.

Data on ecological indices as revealed by this research is not an indication of safe levels of the contaminants, it only reveals significantly low potential ecological risks associated with the levels of the contaminants. Results of human health indices have clearly demonstrated significant potential human health risk of exposure via consumption of food crops contaminated by lead levels which can result in non-carcinogenic diseases such as lead poisoning.

We, therefore, recommend regular and strict quality evaluation of food crops produced from the areas around the abandoned mining sites to prevent possible food poisoning by lead.

\section{Conflicts of Interest}

The authors declare no conflicts of interest regarding the publication of this paper.

\section{References}

[1] Anka, S., Sanda, A., Bello, T.S., Waziri, A.F., Muhammad, A.S., Bello, I., et al. (2020) Environmental Effect of Lead Combination of Mining Communities in Zamfara State, Nigeria: A Review. Journal of Biology and Today's World, 9, 1-3.

[2] Okereafor, U., Makhatha, M., Mekuto, L., Uche-Okereafor, N., Sebola, T. and Mavumengwana, V. (2020) Toxic Metal Implications on Agricultural Soils, Plants, Animals, Aquatic Life and Human Health. International Journal of Environmental Research and Public Health, 17, Article No. 2204. https://doi.org/10.3390/ijerph17072204

[3] David Jr., V.E., John, Y. and Hussain, S. (2020) Rethinking Sustainability: A Review 
of Liberia's Municipal Solid Waste Management Systems, Status, and Challenges. Journal of Material Cycles and Waste Management, 22, 1299-1317. https://doi.org/10.1007/s10163-020-01046-X

[4] Wakenge, C.I., Nyenyezi, M.-R.B., Bergh, S.I. and Cuvelier, J. (2021) From 'Conflict Minerals' to Peace? Reviewing Mining Reforms, Gender, and State Performance in Eastern Democratic Republic of Congo. The Extractive Industries and Society, 8, Article ID: 100894. https://doi.org/10.1016/j.exis.2021.100894

[5] Verbrugge, B. and Geenen, S. (2019) The Gold Commodity Frontier: A Fresh Perspective on Change and Diversity in the Global Gold Mining Economy. The Extractive Industries and Society, 6, 413-423. https://doi.org/10.1016/j.exis.2018.10.014

[6] Atibu, E.K., Lacroix, P., Sivalingam, P., Ray, N., Giuliani, G., Mulaji, C.K., et al. (2018) High Contamination in the Areas Surrounding Abandoned Mines and Mining Activities: An Impact Assessment of the Dilala, Luilu and Mpingiri Rivers, Democratic Republic of the Congo. Chemosphere, 191, 1008-1020. https://doi.org/10.1016/j.chemosphere.2017.10.052

[7] Feng, Y., Wang, J., Bai, Z., Bai, Z. and Reading, L. (2019) Effects of Surface Coal Mining and Land Reclamation on Soil Properties: A Review. Earth-Science Reviews, 191, 12-25. https://doi.org/10.1016/j.earscirev.2019.02.015

[8] Durden, J.M., Lallier, L.E., Murphy, K., Jaeckel, A., Gjerde, K. and Jones, D.O.B. (2018) Environmental Impact Assessment Process for Deep-Sea Mining in 'the Area'. Marine Policy, 87, 194-202. https://doi.org/10.1016/j.marpol.2017.10.013

[9] Fugiel, A., Burchart-Korol, D., Czaplicka-Kolarz, K. and Smoliński, A. (2017) Environmental Impact and Damage Categories Caused by Air Pollution Emissions from Mining and Quarrying Sectors of European Countries. Journal of Cleaner Production, 143, 159-168. https://doi.org/10.1016/j.jclepro.2016.12.136

[10] Merem, E., Twumasi, Y., Wesley, J., Isokpehi, P., Shenge, M., Fageir, S., et al. (2017) Assessing the Ecological Effects of Mining in West Africa: the Case of Nigeria. International Journal of Mining Engineering and Mineral Processing, 6, 1-19. https://doi.org/10.5923/j.mining.20170601.01

[11] Kalu, C. and Uzoamaka, F. (2020) Assessment of Trace Metals Contamination on Soil from Abandoned Artisanal Tin Mining Paddock in Barkin-Ladi Area of Plateau State. International Journal of Advanced Academic Research, 6, 1-18. http://doi.org/10.46654/ij.24889849.e61112

[12] Ghias, S., Hayat Satti, K., Khan, M., Dilband, M., Naseem, A., Jabbar, A., et al. (2021) Health Risk Assessment of Radioactive Footprints of the Urban Soils in the Residents of Dera Ghazi Khan, Pakistan. Chemosphere, 267, Article ID: 129171. https://doi.org/10.1016/j.chemosphere.2020.129171

[13] Idris-Nda, A., Waziri, N.M., Bida, A.D. and Abdullahi, S. (2018) Socio-Economic Impacts of Artisanal and Small-Scale Mining in Parts of Niger State, Central Nigeria. International Journal of Mining Science, 4, 21-30.

[14] National Center for Emerging and Zoonotic Infectious Diseases (NCEZID), National Center for Environmental Health (NCEH) and National Center for Injury Prevention and Control (NCIPC) (2017) Healthy and Safe Swimming Week. May 22-28, 2017.

[15] Getso, K.I., Hadejia, I.S., Sabitu, K., Nguku, P.M., Poggensee, G., Aliyu, H.M., et al. (2014) Prevalence and Determinants of Childhood Lead Poisoning in Zamfara State, Nigeria. Journal of Health Pollution, 4, 1-9. https://doi.org/10.5696/2156-9614-4-6.1

[16] Paul, S.N. and Babatunde, B.B. (2021) Risk Assessment of Poisonous Metals in Wa- 
ter and Soil at Two Abandoned Lead-Zinc Mines at Yonov, Benue State. Asian Journal of Environment Ecology Society, 15, 1-14. https://doi.org/10.9734/ajee/2021/v15i330227

[17] Spencer, B. (2007) Harnessing the Deep Web: A Practical Plan for Locating Free Specialty Databases on the Web. Reference Services Review, 35, 71-83. https://doi.org/10.1108/00907320710729364

[18] Parihar, J.K., Parihar, P.K., Pakade, Y.B. and Katnoria, J.K. (2021) Bioaccumulation Potential of Indigenous Plants for Heavy Metal Phytoremediation in Rural Areas of Shaheed Bhagat Singh Nagar, Punjab (India). Environmental Science and Pollution Research, 28, 2426-2442. https://doi.org/10.1007/s11356-020-10454-3

[19] Wu, H., Yang, F., Li, H., Li, Q., Zhang, F., Ba, Y., et al. (2020) Heavy Metal Pollution and Health Risk Assessment of Agricultural Soil Near a Smelter in an Industrial City in China. International Journal of Environmental Health Research, 30, 174-186. https://doi.org/10.1080/09603123.2019.1584666

[20] Rashed, M. (2010) Monitoring of Contaminated Toxic and Heavy Metals, from Mine Tailings through Age Accumulation, in Soil and Some Wild Plants at Southeast Egypt. Journal of Hazardous Materials, 178, 739-746.

https://doi.org/10.1016/j.jhazmat.2010.01.147

[21] Nawab, J., Farooqi, S., Wang, X., Khan, S. and Khan, A. (2018) Levels, Dietary Intake, and Health Risk of Potentially Toxic Metals in Vegetables, Fruits, and Cereal Crops in Pakistan. Environmental Science and Pollution Research, 25, 5558-5571. https://doi.org/10.1007/s11356-017-0764-x

[22] World Health Organization (1999) Permissible Limits of Heavy Metals in Soil and Plants. World Health Organization, Geneva.

[23] USEPA (2004) Risk Assessment Guidance for Superfund, Volume 1, Human Health Evaluation Manual: Part E, Supplemental Guidance for Dermal Risk Assessment. Report EPA/540/R/99/005, US Environmental Protection Agency, Washington, DC.

[24] USEPA (2011) Screening Level (RSL) for Chemical Contaminant at Super-Found Sites. Regional Screening Tables.

[25] Manoj, K. and Padhy, P. (2014) Distribution, Enrichment and Ecological Risk Assessment of Six Elements in Bed Sediments of a Tropical River, Chottanagpur Plateau: A Spatial and Temporal Appraisal. Journal of Environmental Protection, 5, 1419-1434. https://doi.org/10.4236/jep.2014.514136

[26] Azorji, J., Okechukwu, R., Udebuani, A. and Duru, C. (2021) Evaluation of Physicochemical Properties and Heavy Metal Levels in Soils From Selected Auto Mechanic Workshops in Imo State, Nigeria. Asian Journal of Advances in Research, 8 , 19-29.

[27] Jolly, Y., et al. (2013) Health Risk Assessment of Heavy Metals via Dietary Intake of Vegetables Collected from an Area Selected for Introducing a Nuclear Power Plant. Radiation Science Journal of Physical and Applied Science, 2, 43-51.

[28] Singh, A., Sharma, R.K., Agrawal, M. and Marshall, F. (2010) Risk Assessment of Heavy Metal Toxicity through Contaminated Vegetables from Waste Water Irrigated Area of Varanasi, India. Tropical Ecology, 51, 375-387.

[29] Janadeleh, H. and Kardani, M. (2016) Heavy Metals Concentrations and Human Health Risk Assessment for Three Common Species of Fish from Karkheh River, Iran. Iranian Journal of Toxicology, 10, 31-37.

[30] Ogunwole, G., Abiya, S. and Otitoloju, A. (2019) Illegal Dumpsites and It Impact on Groundwater and Fish Resources (Clarias gariepinus and Oreochromis niloticus). 
International Journal of Environmental Science and Toxicology Research, 7, 1-13.

[31] Wasiu, M.O., Ayodele, O., Oluremi, O., Taoreed, A., Oluwole, E., Temitope, O., et al. (2019) A Particle Induced X-Ray Emission (PIXE) Analysis of Heavy Metals in Soil and Plantain (Musa paradisiaca) Leaves at an Artisanal Gold Mining Settlement in Southwestern Nigeria. Open Journal of Ecology, 9, 200-208.

https://doi.org/10.4236/oje.2019.96016

[32] Arpadjan, S., Celik, G., Taşkesen, S. and Güçer, Ş. (2008) Arsenic, Cadmium and Lead in Medicinal Herbs and Their Fractionation. Food Chemical Toxicology, 46, 2871-2875. https://doi.org/10.1016/j.fct.2008.05.027

[33] Zabbey, N. and Babatunde, B. (2015) Trace Metals in Intertidal Sediment of Mangrove-Sheltered Creeks in Niger Delta, Nigeria: Variability before and after Crude Oil Spillage. African Journal of Environmental Science and Technology, 9, 371-378. https://doi.org/10.5897/AJEST2015.1875

[34] Emmanuel, E., Sombo, T. and Ugwanyi, J. (2018) Assessment of Heavy Metals Concentration in Shore Sediments from the Bank of River Benue, North-Central Nigeria. Journal of Geoscience Environment Protection, 6, 35-48. https://doi.org/10.4236/gep.2018.64003

[35] Zhang, X., Yang, L., Li, Y., Li, H., Wang, W. and Ye, B. (2012) Impacts of Lead/Zinc Mining and Smelting on the Environment and Human Health in China. Environmental Monitoring and Assessment, 184, 2261-2273. https://doi.org/10.1007/s10661-011-2115-6

[36] Simeon, E. and Friday, K. (2017) Index Models Assessment of Heavy Metal Pollution in Soils within Selected Abattoirs in Port Harcourt, Rivers State, Nigeria. Singapore Journal of Scientific Research, 7, 9-15.

[37] Javed, M. and Usmani, N. (2016) Accumulation of Heavy Metals and Human Health Risk Assessment via the Consumption of Freshwater Fish Mastacembelus armatus Inhabiting, Thermal Power Plant Effluent Loaded Canal. SpringerPlus, 5, Article No. 776. https://doi.org/10.1186/s40064-016-2471-3

[38] Ekpete, O.A. and Owhoeke, E. (2019) Risk Assessment of Heavy Metals in Crops and Soil from a Dumpsite in Rumuolumeni, Port Harcourt. Journal of Applied Chemical Science International, 10, 45-52. 